\title{
Tolerance to heavy metal stress in seedlings of three pine species from contrasting environmental conditions in Chile
}

\author{
Ariel D Arencibia, Claudio \\ Rodríguez, Lisandro Roco, \\ Carolina Vergara, Nataly \\ González-Soto, Rolando García- \\ González
}

\begin{abstract}
Tolerance to metal stress was studied in seedlings of three pine species (Pinus radiata, $P$. pinaster and $P$. canariensis) under controlled ex vitro conditions. Mature female cones were randomly collected at two sites in Chile (Llico and Huilquilemu) characterized by contrasting environmental conditions. Oneyear-old pine seedlings were immersed in trays with solutions of $\mathrm{CuSO}_{4}(300$ $\mathrm{mM})$ or $\mathrm{AlCl}_{3}(100 \mathrm{mM})$, and their survival, growth rate and decay symptoms were recorded for 60 days. Results showed large differences among provenances in seedling tolerance to $\mathrm{CuSO}_{4}$ and $\mathrm{AlCl}_{3}$ in terms of survival and growth. Multivariate analysis revealed a significant association $(p<0.0001)$ between the first canonical function and the following variables: provenance, species, metal stress and growing rate, as well as between the second canonical function and provenance, species, metal stress and symptomatology, indicating a high degree of genotype-environment interaction. Moreover, the activity of POX, SOD and CAT enzymes was determined 60 days after the beginning of the experiment in the Llico provenance seedlings. $P$. pinaster showed the highest activity level for all the enzymes considered, while $P$. canariensis and $P$. radiata had intermediate and lowest values, respectively. Differential gene expression among pine seedlings under metal stress with $\mathrm{CuSO}_{4}$ for two genes ( $\mathrm{Cu}-\mathrm{Zn}$-superoxide dismutase and RuBis $\mathrm{Co}$ ) confirmed $P$. pinaster as the most tolerant species to $\mathrm{CuSO}_{4}$ treatment. Our results are consistent with the hypothesis that abiotic stress in the maternal environment can induce a "transgenerational plasticity" which could affect progeny performances. The influence of different genetic backgrounds on the tolerance to heavy metals in pine seedlings is also discussed.
\end{abstract}

Keywords: Pinus spp., Heavy Metals, Abiotic Stresses, Genotype-Environment Interaction

ROS are destructive if protective antioxidant mechanisms are not activated efficiently (Bray et al. 2000).

Copper $(\mathrm{Cu})$ is an essential micronutrient with relevant physiological roles in plant growth and development. However, excessive $\mathrm{Cu}$ can be lethal to plants, causing a range of deleterious effects, such as the inhibition of photosynthesis and pigment synthesis, plasma membrane damage and other metabolic disturbances. The Cu concentration in plant leaves ranges from 5-30 $\mu \mathrm{g} \mathrm{g}^{-1}$ dry weight (DW). Furthermore, some plants have developed mechanisms for
Center for Biotechnology of Natural Resources, Department of Forestry, Faculty of Agronomy and Forestry Sciences, Catholic University of Maule, av.da San Miguel 3605, Talca (Chile)

@ Ariel D Arencibia (arieldarencibia@gmail.com)

Received: Nov 02, 2015 - Accepted: May 02, 2016

Citation: Arencibia AD, Rodríguez C, Roco L, Vergara C, González-Soto N, García-González R (2016). Tolerance to heavy metal stress in seedlings of three pine species from contrasting environmental conditions in Chile. iForest 9: 937-945. - doi: 10.3832/ifor1908-009 [online 2016-08-12]

Communicated by: Claudia Cocozza metal detoxification, including exclusion, compartmentalization and binding to organic ligands such as organic acids, amino acids, phytochelatins (PCs), and metallothioneins (Mts - Cobbett \& Goldbrough 2002, Hall 2002). On the other hand, increasing areas of agricultural lands are acidic, where soil contains high quantities of aluminum (Al - Matsumoto 2000) which is highly toxic to plant growth. Several studies identified Al as a cause of ROS over-production and lipid peroxidation, which affect antioxidant enzyme activities in root tips (Simonovičová et al. 2004, Yadav \& Mohanpuria 2009, Giannakoulas et al. 2010). Furthermore, aluminum-induced cell death has been observed after exposure to high levels of $\mathrm{Al}^{3+}$ (Boscolo et al. 2003, Simonovičová et al. 2004). Therefore, a strong connection between excess $\mathrm{Al}$ and oxidative stress has been proposed in plants (Boscolo et al. 2003, Yamamoto et al. 2003).

To survive oxidative damage, plants have developed non-enzymatic and enzymatic systems to regulate the intracellular levels of ROS (Apel \& Hirt 2004, Sharma \& Dubey 2007). The main non-enzymatic antioxidants are ascorbate (AsA) and glutathione (GSH), while the antioxidative enzymes are Superoxide dismutase (SOD, EC 1.15.1.1), 
Peroxidase (POD, EC1.11.1.7), Catalase (CAT, EC 1.11.1.6), AsA-GSH cycle-related ascorbate peroxidase (APX, EC 1.11.1.11), Monodehydro ascorbate reductase (MDHAR, EC 1.6.5.4), Dehydro ascorbate reductase (DHAR, EC 1.8.5.1), Glutathione peroxidase (GPX, EC 1.11.1.9) and Glutathione reductase (GR, EC 1.6.4.2 - Foyer \& Noctor 2005) Higher activities of antioxidant enzymes facilitate the removal of excessive ROS and suppress lipid peroxidation, which could be beneficial for plant performance under $A$ stress (Apel \& Hirt 2004, Mittler et al. 2004).

Current research on metal tolerance in plants is mainly focused to their adaptation to very restrictive environmental conditions. Our hypothesis was that transgenerational plasticity might influence progeny performance, resulting in a higher probability of selecting tolerant individuals. Thus, the aim of our work was to evaluate the tolerance of three Pinus spp. species, derived from mother plants selected in extreme agroforestry systems, to increasing concentrations of $\mathrm{Cu}$ and $\mathrm{Al}$ under controlled ex vitro conditions. Both biochemical and differential gene expression analyses were conducted to support the tolerance screening experiments. The final goal of thi study was the selection of $\mathrm{Cu}$ - and $\mathrm{Al}$ tolerant Pinus spp. plants, suitable for greenhouse or trials under metal contamination.

\section{Materials and methods}

\section{Plant material}

Mature female cones from $P$. radiata, $P$. pinaster and $P$. canariensis were randomly collected from two contrasting localities: (a) the Forestry Reserve "Laguna Torca" (CONAF - Corporación Forestal Nacional, Chilean Forest Service) is a protected area located in Llico $\left(34^{\circ} 46^{\prime} \mathrm{S}, 72^{\circ} 6^{\prime} \mathrm{W}\right.$ ), near to a marine environment with a mixture of sandy soil; (b) the Experimental Station of the Catholic University of Maule located in Huilquilemu $\left(35^{\circ} 27^{\prime} \mathrm{S}, 71^{\circ} 34^{\prime} \mathrm{W}\right)$ in the Central Valley is characterized by arable and fertile soil. Both localities belong to the Maule Region, Chile, though they are geographically separated by the coastal mountain range.

For seed release, the cones were immersed in hot water $\left(50^{\circ} \mathrm{C}\right)$ for 2 min and then transferred to $40{ }^{\circ} \mathrm{C}$ for $48 \mathrm{~h}$ (dry treatment). Racks of 64 small pots containing a soil vermiculite mixture (1:1) were used for single-seed sowing. At the beginning of the spring season (August), seed germination was carried out in ex vitro controlled conditions.

\section{Experimental treatments}

One-year-old seedlings from $P$. radiata, $P$. pinaster and $P$. canariensis populations were selected for abiotic stress experiments with $\mathrm{CuSO}_{4}$ and $\mathrm{AlCl}_{3}$. Seedlings were planted in single plastic pots containing the vermiculite soil mixture. The roots of the pine plants were immersed in trays with solutions of increasing $\mathrm{CuSO}_{4}$ concentrations $(100 \mathrm{mM}, 200 \mathrm{mM}, 300 \mathrm{mM})$ or $\mathrm{AlCl}_{3}(50 \mathrm{mM}, 100 \mathrm{mM})$. The combinations of Pinus spp. genotypes (populations) with metal stress treatments resulted in a total of 15 experimental variants per site (Llico, Huilquilemu). Control treatments for the three pine species in each locality were immersed in distilled water. A total of 96 plants per treatment were placed in two replica trays (48 pots/tray) following a factorial block design. A total of 72 trays (6o for treatments, 12 for controls) were used in the experiment. During the beginning of the spring season (August-September) the experiment was conducted under ex vitro controlled conditions, while plantlets were totally covered with protective mesh (sunlight reduced by 50\%). Both fresh weight (FW) and dry weight (DW) at $\mathrm{T}_{0}$ (before the stress treatments) and $T_{F}$ (after 60 days of stress treatments) were determined for needles $(N)$, stem $(S)$ and roots $(R)$ of individual Pinus spp. seedlings. The number of dead plants (NDP), number of symptomatic plants (NSP) and the growing rate (GR) under treatments were estimated at $0,15,30,45$ and 60 days.

\section{Samples for enzyme activity} determination and DNA analysis

Approximately $1.0 \mathrm{~g}$ of needles (20 plants, two needles per plant) for each block (48 plants) of treatments, were pooled at 0,15 , 30, 45 and 60 days. Plants were randomly selected including both symptomatic and asymptomatic individuals. Two replicas per treatment were determined for the enzymatic activities. For RT-PCR analysis, a single sample per treatment was conducted pooling one needle of 40 randomly selected plants per treatment.

\section{Peroxidase (POX) assay}

POX activity was assessed according to Bania \& Mahanta (2012). Briefly, $2 \mathrm{ml}$ of

Tab. 1 - Information of the selected genes analyzed by RT-PCR in Pinus spp.

\begin{tabular}{clllcc}
\hline No & $\begin{array}{l}\text { Accession } \\
\text { number }\end{array}$ & $\begin{array}{l}\text { Protein/ } \\
\text { Function }\end{array}$ & Primers (5'-3') & $\begin{array}{c}\text { Tm } \\
\left({ }^{\circ} \mathbf{C}\right)\end{array}$ & $\begin{array}{c}\text { Size } \\
(\mathbf{b p})\end{array}$ \\
\hline 1 & AF434186 & $\begin{array}{l}\text { P. pinaster Cu-Zn- } \\
\text { superoxide dismutase } \\
\text { precursor }\end{array}$ & I - ATAGTTGCGGGTTCTGATGG & 59.96 & 203 \\
r - ATGGGAGTGAGTCCAACCAC & 59.82 & \\
\hline 2 & AJ309096 & $\begin{array}{l}\text { P. pinaster ribulose- } \\
\text { bisphosphate carboxylase } \\
\text { (RuBisCo) small chain }\end{array}$ & I - AACAAGTGGGTGCCTTGTCT & 59.62 & 210 \\
\hline
\end{tabular}

phosphate buffer ( $\mathrm{pH}$ 6.0/7.0), $100 \mu \mathrm{l}$ of plant extract, and $1 \mathrm{ml}$ of $\mathrm{O}$-dianisidine solution were mixed. The reaction was initiated by adding $100 \mu \mathrm{l}$ of $0.2 \mathrm{mM} \mathrm{H}_{2} \mathrm{O}_{2}$ and the absorbance was read at $460 \mathrm{~nm}$ at $30 \mathrm{sec}$ ond intervals for 5 minutes. Peroxidase activity was calculated using an extinction co-efficient of O-dianisidine and enzyme activity was expressed as unit per $\mathrm{mg}$ of protein.

\section{Superoxide dismutase (SOD) assay}

SOD activity was monitored according to the method from Roth \& Gilbert (1984) and modified by Kumar et al. (2009). One $\mathrm{ml}$ of reaction mixture contained $50 \mathrm{mM}$ sodium phosphate buffer ( $\mathrm{pH} 7.8), 100 \mathrm{mM}$ EDTA, $20 \mathrm{ml}$ enzyme extract, and $10 \mathrm{mM}$ pyrogallol. Enzyme activity [U (mg protein) $\left.{ }^{-1}\right]$ was calculated by monitoring the reaction mixture for $120 \mathrm{~s}$ (at $60 \mathrm{~s}$ intervals) at $420 \mathrm{~nm}$ in a spectrophotometer.

\section{Catalase (CAT) assay}

CAT activity was assayed by measuring the initial rate of $\mathrm{H}_{2} \mathrm{O}_{2}$ disappearance using the method of Beers \& Sizer (1952) reported by Kumar et al. (2009). One $\mathrm{ml}$ of catalase assay reaction mixture contained $0.05 \mathrm{mM}$ sodium phosphate buffer $(\mathrm{pH}$ 7.0), $20 \mathrm{ml}$ enzyme extract and $1 \mathrm{mM} \mathrm{H}_{2} \mathrm{O}_{2}$. The decrease in $\mathrm{H}_{2} \mathrm{O}_{2}$ was followed by a decline in $\mathrm{A}_{240}$, and the activity [ $\mathrm{U}$ (mg protein $\left.)^{-1}\right]$ was calculated using a molar absorption coefficient of $40 \mathrm{mM}^{-1} \mathrm{~cm}^{-1}$ for $\mathrm{H}_{2} \mathrm{O}_{2}$.

\section{RT-PCR analysis}

RT-PCRs were conducted according to Yang et al. (2010). RNA was extracted from the leaves (middle part) pooled from separate replicates. Extractions were performed using the $\mathrm{TRIzO}^{\circledast}$ reagent (Invitrogen, Carlsbad, CA, USA). One g of pooled, frozen leaf tissue was ground to a fine powder in the presence of liquid nitrogen, and then mixed with $10 \mathrm{ml}$ TRIzol. RNA sample concentrations were quantified by determining the 260:280 and 260:230 nm ratios by spectrophotometry and further confirmed on a $1.2 \%$ agarose/0.4 M formaldehyde gel. Twenty ng of high quality RNA was added as template to each reaction using the Enhanced Avian HS RTPCR kit ${ }^{\oplus}$ (Sigma, St. Louis, MO, USA). For specific RT-PCR amplification, genes were selected and oligonucleotide primers were designed using sequences from the GenBank public databases (http://www.ncbi.nlm.nih.gov). Information on primer source, nucleotide sequence, and PCR annealing temperatures are listed in Tab. 1.

The $P C R$ reaction mixture consisted of 3 $\mu \mathrm{l}$ of first strand cDNA, $5 \mu \mathrm{l}$ of $10 \times$ PCR buffer, $5 \mu \mathrm{l}$ of $25 \mathrm{mM} \mathrm{MgCl}, 1 \mu \mathrm{l}$ of dNTPs (10 $\mathrm{mM}$ each), $1 \mu \mathrm{l}$ of each $10 \mu \mathrm{M}$ primers (forward and reverse), $1 \mathrm{U}$ of Taq DNA polymerase (Invitrogen), and ultrapure water (Sigma) to a final volume of $50 \mu \mathrm{l}$. PCRs were conducted with the following parameters: $94{ }^{\circ} \mathrm{C}$ for $3 \mathrm{~min}, 30 \mathrm{cycles}$ of $94{ }^{\circ} \mathrm{C}$ for 
$30 \mathrm{~s}$, annealing at $59^{\circ} \mathrm{C}$ for $30 \mathrm{~s}$ (Tab. 1), 72 ${ }^{\circ} \mathrm{C}$ for $1 \mathrm{~min}$ followed by a final incubation at $72{ }^{\circ} \mathrm{C}$ for $10 \mathrm{~min}$. RT-PCR products were separated on a $1 \%$ agarose gel and stained with ethidium bromide.

\section{Statistical analysis}

Using data recorded on day 60 , the relationship between the independent variables (localities, species, metal stresses) and dependent variables (GR or growing rate, NSP or symptomatology, NDP or plant survival) were compared using nonparametric statistical tests, due to the nature of the data (categorical variables and non-normal distributions). The Kruskal-Wallis $\mathrm{H}$ test was used to test for differences among groups, while the Mann-Whitney $U$ test for the pairwise comparison between groups. Additionally, data were investigated using Canonical Variant Analysis (CVA) as described by Cankaya et al. (2010), to determine the correlation between sets of variables from the same samples. According to Ter Braak (1986), CVA is an ordi- nation technique which impose the extra restriction that the axes be linear combinations of environmental variables. Using this approach, the community variation can be directly associated with the environmental variation, and environmental variables may be quantitative or nominal (Coleman et al. 2008). The redundancy index is a measure of the variance of one set of variables predicted from the linear combination of the other set of variables. Pearson's correlation is used to analyze the linear relationship between two sets of data. Enzyme activities of POX, SOD and CAT during the experimental course were analyzed by ANOVA.

\section{Results}

\section{Metal stress symptoms}

One-year-old plants of $P$. radiata, $P$. pinaster and $P$. canariensis from the contrasting localities of Llico and Huilquilemu were stressed under increasing concentrations of $\mathrm{CuSO}_{4}(100 \mathrm{mM}, 200 \mathrm{mM}, 300 \mathrm{mM})$ and $\mathrm{AlCl}_{3}(50 \mathrm{mM}, 100 \mathrm{mM})$. Tests were conducted under ex vitro, controlled conditions, where a protective mesh $(25 \mathrm{~m} \times 25$ $\mathrm{m}$ ) was used as a closed chamber to maintain the homogeneity of variable incidences associated with evapotranspiration, and to reduce possible spatial effects. After one week of stress treatments, phenotypic changes were consistently visible in the non-tolerant plants. Symptoms started from the basal part of the seedlings, and migrated to the upper fraction during the experiment. At the beginning of induced stress with either $\mathrm{CuSO}_{4}$ or $\mathrm{AlCl}_{3}$, the leaves were a pale yellow color, which after 60 days turned into a mixture of opaque gray and shades of red. Tolerant plants preserved the green color of leaves; however, after 60 days some of the leaves showed non-lethal symptoms in their basal and mid sections.

$P$. pinaster showed the best results under both $200 \mathrm{mM} \mathrm{CuSO}_{4}$ and $300 \mathrm{mM} \mathrm{CuSO}_{4}$ (Fig. 1), while both $\mathrm{P}$. pinaster and $\mathrm{P}$. canariensis showed tolerance to $100 \mathrm{mM} \mathrm{AlCl}{ }_{3}$
Fig. 1 - General symptoms of pine plants under abiotic stress from $\mathrm{CuSO}_{4}$ treatment in controlled ex vitro conditions. (A): $P$. radiata ;

(B): P. canariensis; (C): $P$. pinaster.

A
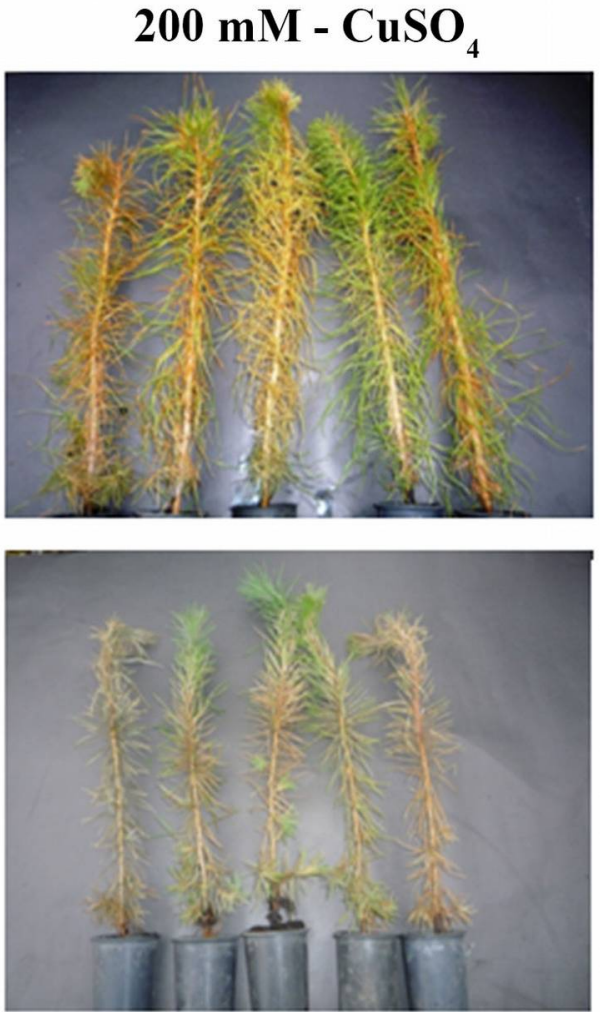

\section{B}

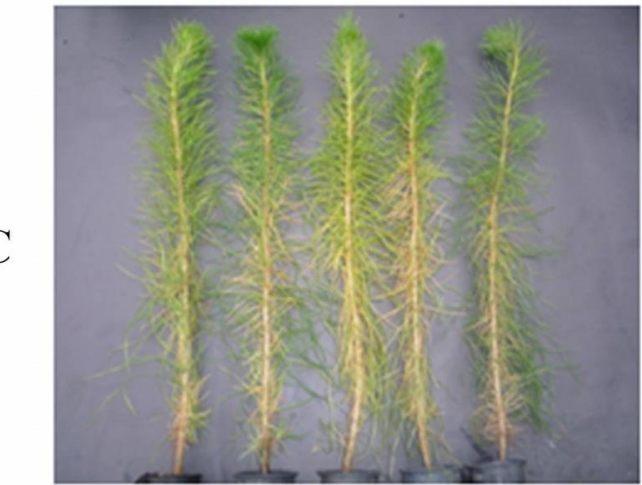

$300 \mathrm{mM}-\mathrm{CuSO}_{4}$
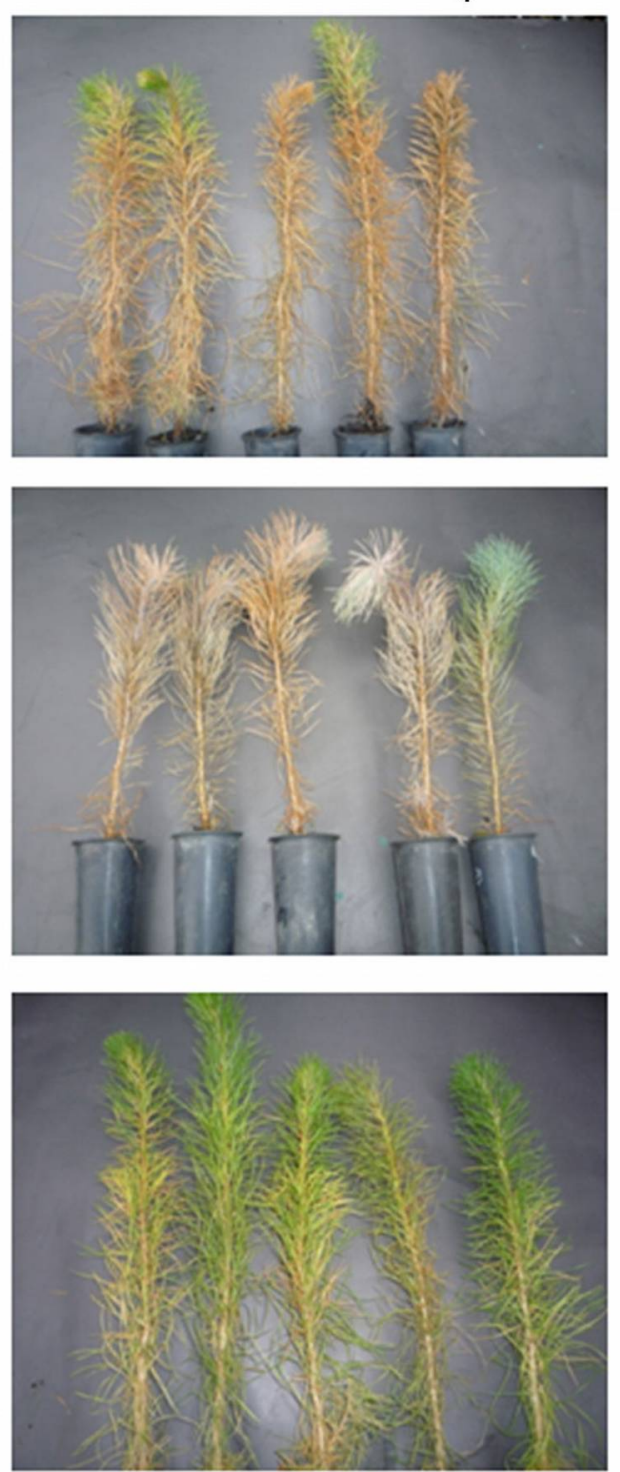


\section{$100 \mathrm{mM} \mathrm{AlCl}_{3}$}
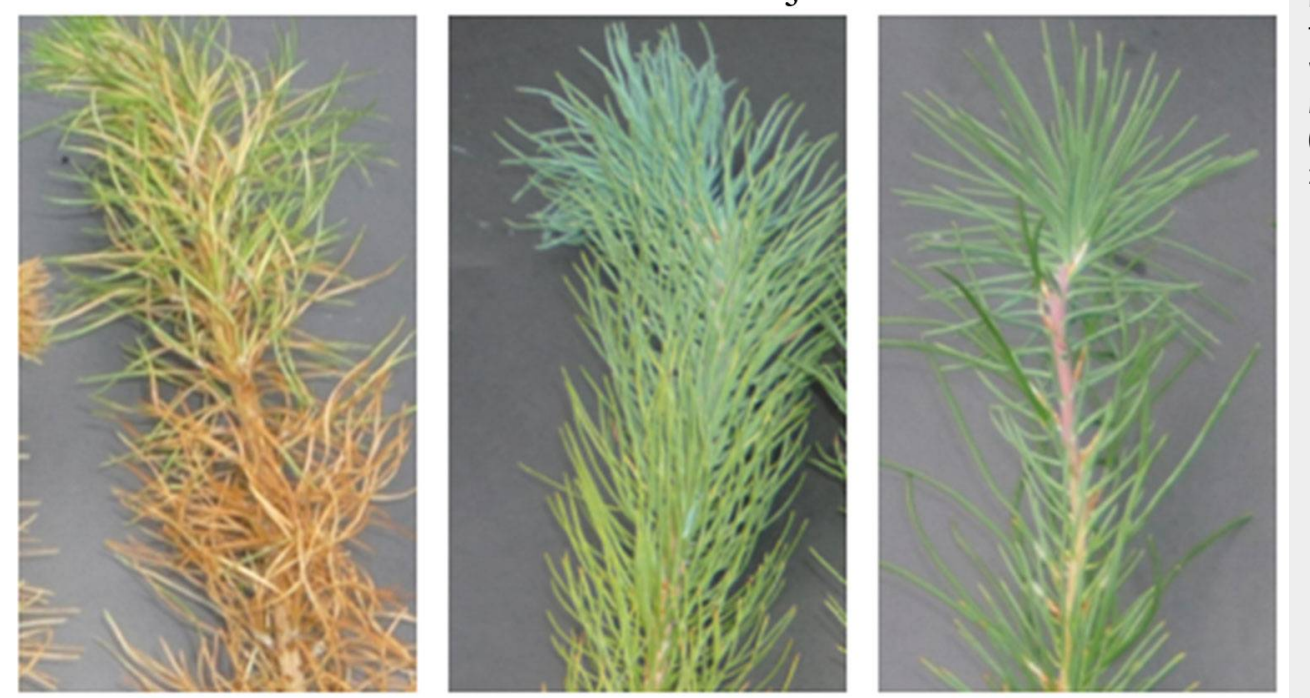

Fig. 2 - Details of symptoms in pine plants under $\mathrm{AlCl}_{3}$ treatment in controlled ex vitro conditions. (A): $P$. radiata; (B): $P$. canariensis; (C): P. pinaster; (I): apical zone; (II): basal zone.

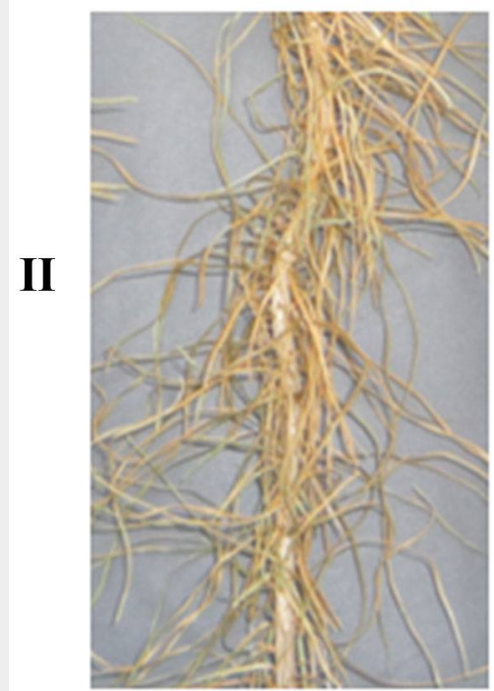

A

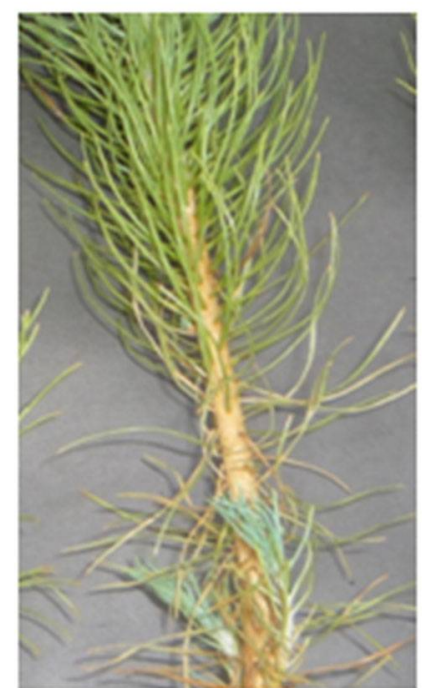

B
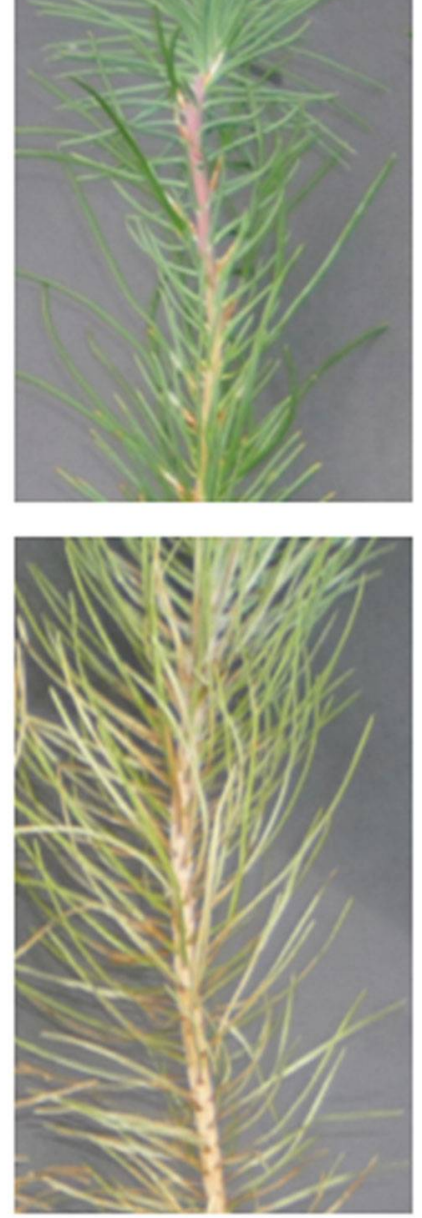

C
(Fig. 2). P. radiata had intense foliar damage, which evolved to plant death in a significant number of individuals. Contrastingly, control treatments (three pine species from each site) immersed in distilled water remained with an intense green color, indicating the optimal physiological quality of the starting materials and their expected behavior during the experimental time (data not shown).

\section{Seedling growth and survival}

The characterization of metal tolerance was estimated by the NDP and NSP after 60 days of stress. Considering the most consistent phenotypic contrast between the tolerant and non-tolerant plants, only seedlings grown under $300 \mathrm{mM} \mathrm{CuSO}_{4}$ and $100 \mathrm{mM} \mathrm{AlCl}_{3}$ treatments were selected for further experiments and data analysis.

Differences in the number of tolerant plants (NTP) were verified between Pinus spp., where $P$. pinaster displayed the highest NTP values $(57.3 \%$ of individuals tolerant to $\mathrm{CuSO}_{4}$ or $\mathrm{AlCl}_{3}$ ). However, a remarkable influence of the seed provenance was detected (Tab. 2), being plantlets germinated from seeds collected in Llico more tolerant to metal stresses than those from Huilquilemu ( $87.4 \%$ vs. $12.6 \%$, respectively).

Using exploratory univariate statistical

Tab. 2 - Tolerance to metal stresses of Pinus spp. seedlings from the provenances Llico and Huilquilemu after 60 days. (NSP): number of symptomatic plants; (NDP): number of dead plants; (NTP): number of tolerant plants.

\begin{tabular}{|c|c|c|c|c|c|c|c|c|c|c|c|c|c|}
\hline \multirow{3}{*}{$\begin{array}{l}\text { Locality / } \\
\text { metal stress / } \\
\text { variable }\end{array}$} & \multicolumn{6}{|c|}{ Llico } & \multicolumn{6}{|c|}{ Huilquilemu } & \multirow{3}{*}{$\begin{array}{l}\text { Tolerant } \\
\text { plants }\end{array}$} \\
\hline & \multicolumn{3}{|c|}{$\mathrm{CuSO}_{4}(300 \mathrm{mM})$} & \multicolumn{3}{|c|}{$\mathrm{AlCl}_{3}(100 \mathrm{mM})$} & \multicolumn{3}{|c|}{$\mathrm{CuSO}_{4}(300 \mathrm{mM})$} & \multicolumn{3}{|c|}{$\mathrm{AlCl}_{3}(100 \mathrm{mM})$} & \\
\hline & NSP & NDP & NTP & NSP & NDP & NTP & NSP & NDP & NTP & NSP & NDP & NTP & \\
\hline P. radiata & 96 & 76 & 20 & 96 & 63 & 33 & 96 & 91 & 5 & 96 & 92 & 4 & $62(17.9 \%)$ \\
\hline P. canariensis & 96 & 80 & 16 & 58 & 36 & 60 & 96 & 89 & 7 & 96 & 93 & 3 & $86(24.8 \%)$ \\
\hline P. pinaster & 84 & 6 & 90 & 57 & 12 & 84 & 96 & 82 & 14 & 96 & 85 & 11 & 199 (57.3\%) \\
\hline Tolerant plants/treatment & - & - & 126 & - & - & 177 & - & - & 26 & - & - & 18 & $347(100 \%)$ \\
\hline Tolerant plants/locality & \multicolumn{3}{|c|}{$303(87.4 \%)$} & & & & \multicolumn{3}{|c|}{$44(12.6 \%)$} & & & & 347 (100\%) \\
\hline
\end{tabular}


analysis (Mann-Whitney $U$ test), significant differences were found in symptomatology and plant survival in relation to the site and the pine species (Tab. 3). No significant differences in growth rate were detected between $P$. radiata and $P$. canariensis, while they both differed from $P$. pinaster, which had the highest values. Seedlings from Llico showed the highest growth rate and displayed significant differences in comparison with seedlings of mother plants from Huilquilemu.

A time course of the experiments with seedlings from the Llico provenance was estimated (Fig. 3). P. pinaster showed the best results with the lowest number of dead plants under either $300 \mathrm{mM} \mathrm{CuSO}_{4}$ or $100 \mathrm{mM} \mathrm{AlCl}_{3}$ treatments. Overall, the NSP was higher than the NDP, depending on the species and metal stress treatments.

\section{Canonical variant analysis}

Canonical variant analysis (CVA) was applied to test for correlations between experimental factors and response variables. To set the canonical functions, three independent variables (i.e., locality, Pinus species and metal stress) were recognized as group 1 (genotype-environment interaction), while the three dependent variables (i.e., growth rate, symptomatology and plant survival) were referred to as group 2 (tolerance to metal stress).

The Pearson's correlation analysis between the CVA dimensions of groups 1 and 2 revealed low though significant correlation coefficients (Tab. 4). The highest correlations were detected between metal stress and tolerance variables, with a maximum value of 0.295 between plant survival and metal stress.

Canonical functions reflect the correlations between latent variables in their possible combinations (Tab. 5). Since there were three variables as original criteria,

Tab. 3 - Exploratory univariate analysis for different groups of variables. Different letters in the same column indicate significant differences between the means after Mann-Whitney $U$ test $(p<0.05)$.

\begin{tabular}{|c|c|c|c|c|}
\hline \multirow[b]{2}{*}{ Group } & \multirow[b]{2}{*}{ Variable } & \multicolumn{3}{|c|}{ Mean } \\
\hline & & $\begin{array}{c}\text { Growth rate } \\
(\mathrm{cm})\end{array}$ & $\begin{array}{l}\text { Symptomatology } \\
\text { (scale } 1 \text { to } 4 \text { ) }\end{array}$ & $\begin{array}{l}\text { Plant } \\
\text { survival }\end{array}$ \\
\hline \multirow[t]{2}{*}{ Location } & Llico & $0.772^{a}$ & $3.58^{\mathrm{a}}$ & $0.20^{\mathrm{a}}$ \\
\hline & Huilquilemu & $0.241^{\mathrm{b}}$ & $3.86^{\mathrm{b}}$ & $0.06^{b}$ \\
\hline \multirow[t]{3}{*}{ Species } & $P$. radiata & $0.204^{\mathrm{b}}$ & $3.87^{c}$ & $0.06^{c}$ \\
\hline & P. canariensis & $0.314^{\mathrm{b}}$ & $3.78^{\mathrm{b}}$ & $0.10^{\mathrm{b}}$ \\
\hline & P. pinaster & $0.923^{\mathrm{a}}$ & $3.50^{\mathrm{a}}$ & $0.23^{a}$ \\
\hline \multirow[t]{2}{*}{ Metal stress } & $300 \mathrm{mM} \mathrm{CuSO}_{4}$ & 1.180 & 3.34 & 0.31 \\
\hline & $100 \mathrm{mM} \mathrm{AlCl}_{3}$ & 1.241 & 3.26 & 0.35 \\
\hline
\end{tabular}

Tab. 4 - Matrix of correlations between variables of groups 1 (locality, species and metal stress) and 2 (growth rate, symptomatology and plant survival). $(* * *): p<0.001$.

\begin{tabular}{lccc}
\hline \multirow{2}{*}{ Response variables } & \multicolumn{3}{c}{ Factors } \\
\cline { 2 - 4 } & Locality & Species & Metal stress \\
\hline Growth rate & $-0.181076^{* * *}$ & $0.231419^{* * *}$ & $0.275085^{* * *}$ \\
Symptomatology & $0.186185^{* * *}$ & $-0.196181^{* * *}$ & $-0.274277^{* * *}$ \\
Plant survival & $-0.211238^{* * *}$ & $0.202894^{* * *}$ & $0.295173^{* * *}$ \\
\hline
\end{tabular}

only three canonical functions were extracted: (1) locality-species-metal stressgrowing rate; (2) locality-species-metal stress-symptomatology; and (3) localityspecies-metal stress-plant survival. Results indicated a significant $(\mathrm{p}<0.0001)$ association between these groups for functions 1 and 2 , and a high degree of correlation $(r=$ 0.417 ) for function 1.

As for function 1, the proportion of variance of the metal stress tolerance variables (set 2) explained by the genotype-environment interaction variables (set 1$)$ was 0.173 $\left(R_{\text {canonical }}=0.417\right)$, while it was $0.020\left(R_{\text {canonical }}\right.$ $=0.143$ ) for the canonical function 2 (Tab. 5).

The redundancy index is a measure of the ability of original variables (locality, species and metal stress) taken together, to explain the variation in the criterion variables (namely, growing rate, symptomatology and plant survival). Canonical correlation weights (i.e., the impact of each variable on the canonical function) demonstrated that function 1 was mainly influenced by plant survival, metal stress, species and locality variables, while function 2 was mostly affected by the species, symptomatology and locality (Tab. 6).

\section{Enzyme activity}

In the case of seedlings from the Llico provenance, the enzyme activity of POX, SOD and CAT was determined after 60 days since the beginning of the experiment. For $300 \mathrm{mM} \mathrm{CuSO}_{4}$ and $100 \mathrm{mM} \mathrm{AICl}_{3}$
Fig. 3 - Tolerance of pine seedlings (Llico provenance) to $\mathrm{CuSO}_{4}$ (a-b) and $\mathrm{AlCl}_{3}(\mathrm{c}-\mathrm{d})$ treatments under controlled conditions. (a) Number of symptomatic plants (NSP) at $300 \mathrm{mM} \mathrm{CuSO}_{4}$; (b): number of dead plants (NDP) at $300 \mathrm{mM}$ $\mathrm{CuSO}_{4}$; (c): NSP at 100 $\mathrm{mM} \mathrm{AlCl}$; (d): NDP at 100 $\mathrm{mM} \mathrm{AlCl}$.

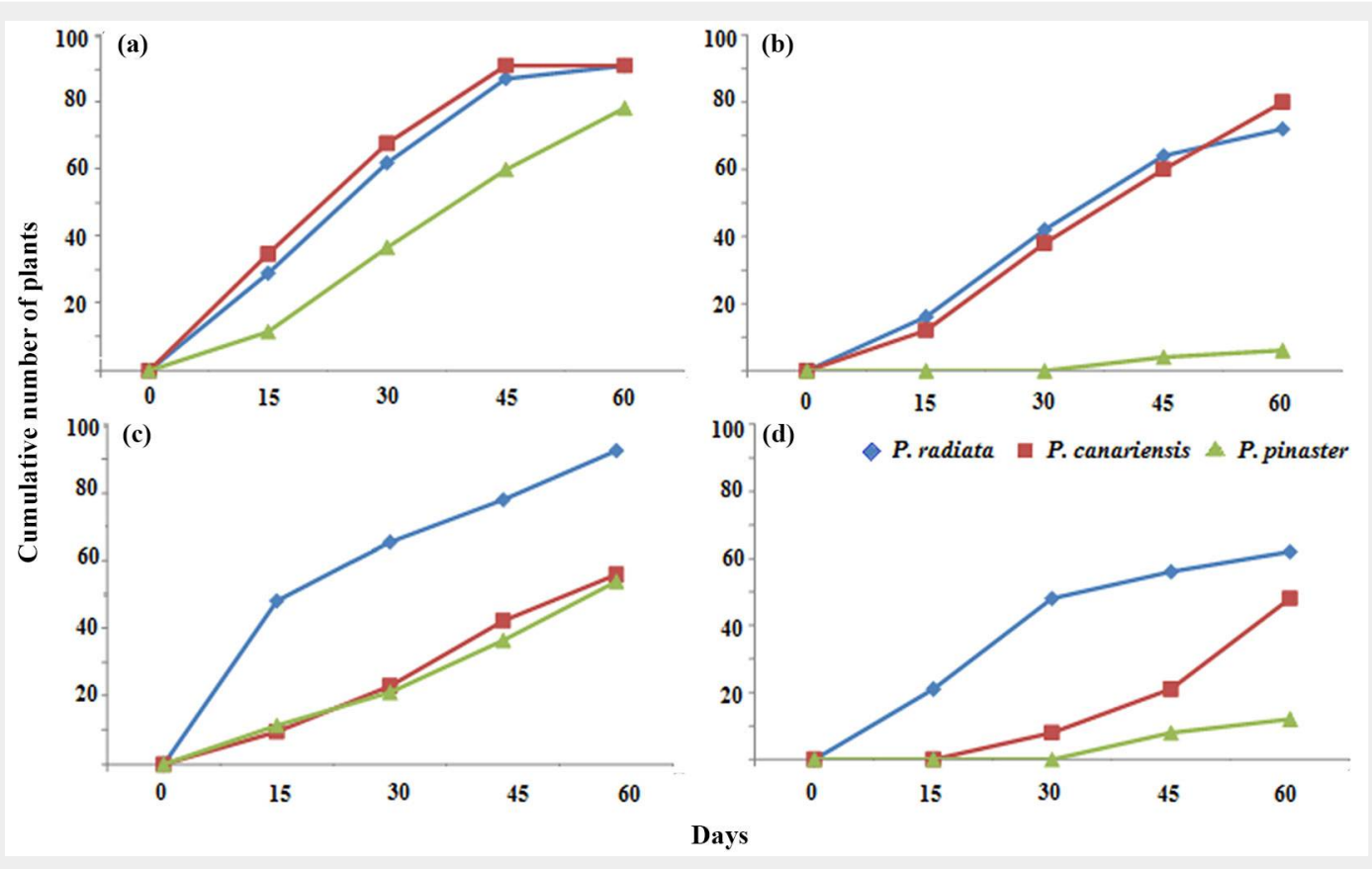


Tab. 5 - Significance and redundancy index of canonical functions.

\begin{tabular}{cccrrrrr}
\hline Function & R canonical & Square & \multicolumn{1}{c}{$\chi^{2}$} & dg & p-value & $\begin{array}{c}\text { Prop. of } \\
\text { variance }\end{array}$ & Redundancy \\
\hline 1 & 0.417079 & 0.17396 & 304.0054 & 9 & $<0.0001$ & 0.923265 & 0.160606 \\
2 & 0.142656 & 0.02035 & 29.8647 & 4 & $<0.0001$ & 0.022106 & 0.000450 \\
3 & 0.016064 & 0.00026 & 0.3702 & 1 & 0.5429 & 0.054629 & 0.000014 \\
\hline
\end{tabular}

Tab. 6 - Correlations between canonical functions and the original variables.

\begin{tabular}{llccc}
\hline \multirow{2}{*}{ Kind } & \multirow{2}{*}{ Variables } & \multicolumn{3}{c}{ Canonical functions } \\
\cline { 3 - 5 } & & $\mathbf{1}$ & $\mathbf{2}$ & $\mathbf{3}$ \\
\hline Factors & Locality & 0.498843 & 0.50699 & -0.702936 \\
& Species & -0.505099 & 0.82943 & 0.238567 \\
& Metal stress & -0.704108 & -0.23454 & -0.670241 \\
Response & Growing rate & -0.245276 & 0.45572 & 0.843858 \\
variables & Symptomatology & -0.224864 & 0.63288 & 0.198845 \\
& Plant survival & -0.975096 & -0.44654 & 0.149508 \\
\hline
\end{tabular}

treatments, randomized samples were se- sis and $P$. radiata. In the case of SOD, lected from the middle parts of five plants enzyme activity was higher in P. pinaster per treatment. For $P$. pinaster seedlings, than in P. canariensis and P. radiata. For all POX activity increased in both treatments, the three pine species, SOD activity in while it decreased drastically in P. canarien- seedlings grown under $\mathrm{AlCl}_{3}$ treatment increased during the first 30 days, whereas it severely decreased in $P$. radiata plants after 60 days (Tab. 7 ).

Additionally, CAT activity showed the highest values for $P$. canariensis after 15 $(300 \mathrm{mM} \mathrm{CuSO})_{4}$ ) and 30 days $(100 \mathrm{mM}$ $\mathrm{AlCl}_{3}$ ); however, these enzymatic values decreased during the experiment. At the end of the experiments (60 days), CAT activity was highest in $P$. pinaster seedlings in both stress treatments. Overall, P. pinaster plants showed the highest level of enzyme activity, followed by $P$. canariensis (intermediate) and $P$. radiata, which showed the lowest enzymatic values.

\section{RT-PCR analysis}

Transcriptional activities of Cu-Zn-superoxide dismutase and Ribulose bisphosphate carboxylase (RuBisCo) were measured by semi-quantitative RT-PCRs of selected individuals. Differential gene expression analysis was conducted in pine plants treated with $300 \mathrm{mM} \mathrm{CuSO}_{4}$. P. radiata showed transcript expression only at 15 days for $\mathrm{Cu}$-Zn-superoxide dismutase and at 30 days in the case of RuBisCo (Fig. 4),

Tab. 7 - Time course of POX, SOD and CAT enzyme activities [in $U$ (mg protein) ${ }^{-1}$ ] in pine seedlings from the Llico provenance, treated with $300 \mathrm{mM} \mathrm{CuSO}_{4}$ or $100 \mathrm{mM} \mathrm{AlCl}_{3}$. Values are means \pm standard deviation of three determinations per replica. Different letters in the same column indicate significant differences between the means after ANOVA $(p<0.05)$.

\begin{tabular}{|c|c|c|c|c|c|c|c|}
\hline Treatment & Enzyme & Species & $\mathrm{T}_{\mathrm{o}}$ & 15 Days & 30 Days & 45 Days & 60 Days \\
\hline \multirow[t]{9}{*}{$300 \mathrm{mM} \mathrm{CuSO}_{4}$} & POX & P. pinaster & $1.30 \pm 0.51^{\mathrm{a}}$ & $1.48 \pm 0.43^{\mathrm{a}}$ & $1.52 \pm 0.62^{\mathrm{a}}$ & $1.53 \pm 0.41^{\mathrm{a}}$ & $1.53 \pm 0.45^{\mathrm{a}}$ \\
\hline & & P. canariensis & $0.81 \pm 0.23^{b}$ & $0.62 \pm 0.13^{b}$ & $0.42 \pm 0.19^{\mathrm{b}}$ & $0.23 \pm 0.11^{\mathrm{b}}$ & $0.08 \pm 0.03^{b}$ \\
\hline & & P. radiata & $0.48 \pm 0.11^{c}$ & $0.32 \pm 0.09^{c}$ & $0.25 \pm 0.14^{\mathrm{b}}$ & $0.24 \pm 0.15^{b}$ & $0.07 \pm 0.03^{b}$ \\
\hline & SOD & P. pinaster & $0.42 \pm 0.12^{\mathrm{a}}$ & $0.44 \pm 0.21^{\mathrm{a}}$ & $0.45 \pm 0.11^{\mathrm{a}}$ & $0.45 \pm 0.16^{\mathrm{a}}$ & $0.44 \pm 0.15^{a}$ \\
\hline & & P. canariensis & $0.43 \pm 0.11^{\mathrm{a}}$ & $0.39 \pm 0.16^{\mathrm{a}}$ & $0.35 \pm 0.08^{\mathrm{b}}$ & $0.33 \pm 0.09^{b}$ & $0.25 \pm 0.10^{\mathrm{b}}$ \\
\hline & & P. radiata & $0.35 \pm 0.10^{\mathrm{b}}$ & $0.27 \pm 0.13^{b}$ & $0.20 \pm 0.11^{c}$ & $0.12 \pm 0.04^{c}$ & $0.09 \pm 0.03^{c}$ \\
\hline & CAT & P. pinaster & $1.22 \pm 0.34^{\mathrm{a}}$ & $1.21 \pm 0.29^{\mathrm{a}}$ & $1.20 \pm 0.21^{\mathrm{a}}$ & $1.20 \pm 0.35^{\mathrm{a}}$ & $1.19 \pm 0.31^{\mathrm{a}}$ \\
\hline & & P. canariensis & $1.25 \pm 0.26^{\mathrm{a}}$ & $1.27 \pm 0.31^{\mathrm{a}}$ & $1.21 \pm 0.34^{\mathrm{a}}$ & $1.12 \pm 0.22^{\mathrm{a}}$ & $1.05 \pm 0.19^{\mathrm{a}}$ \\
\hline & & P. radiata & $1.24 \pm 0.30^{\mathrm{a}}$ & $1.22 \pm 0.36^{\mathrm{a}}$ & $1.11 \pm 0.36^{\mathrm{a}}$ & $0.73 \pm 0.11^{\mathrm{b}}$ & $0.62 \pm 0.15^{b}$ \\
\hline \multirow[t]{9}{*}{$100 \mathrm{mM} \mathrm{AlCl}_{3}$} & POX & P. pinaster & $0.72 \pm 0.21^{\mathrm{a}}$ & $0.84 \pm 0.17^{a}$ & $0.85 \pm 0.24^{a}$ & $0.86 \pm 0.29^{a}$ & $0.86 \pm 0.31^{\mathrm{a}}$ \\
\hline & & P. canariensis & $0.69 \pm 0.17^{\mathrm{a}}$ & $0.65 \pm 0.15^{\mathrm{b}}$ & $0.42 \pm 0.19^{b}$ & $0.25 \pm 0.12^{b}$ & $0.15 \pm 0.06^{\mathrm{b}}$ \\
\hline & & P. radiata & $0.65 \pm 0.20^{\mathrm{a}}$ & $0.49 \pm 0.11^{\mathrm{b}}$ & $0.28 \pm 0.14^{\mathrm{b}}$ & $0.22 \pm 0.09^{b}$ & $0.13 \pm 0.05^{\mathrm{b}}$ \\
\hline & SOD & P. pinaster & $0.31 \pm 0.13^{\mathrm{a}}$ & $0.43 \pm 0.14^{\mathrm{a}}$ & $0.42 \pm 0.10^{\mathrm{a}}$ & $0.40 \pm 0.18^{\mathrm{a}}$ & $0.39 \pm 0.10^{\mathrm{a}}$ \\
\hline & & P. canariensis & $0.30 \pm 0.11^{\mathrm{a}}$ & $0.35 \pm 0.19^{\mathrm{ab}}$ & $0.34 \pm 0.07^{b}$ & $0.31 \pm 0.08^{\mathrm{b}}$ & $0.26 \pm 0.12^{\mathrm{b}}$ \\
\hline & & P. radiata & $0.26 \pm 0.12^{\mathrm{a}}$ & $0.27 \pm 0.16^{\mathrm{b}}$ & $0.21 \pm 0.11^{b c}$ & $0.18 \pm 0.09^{c}$ & $0.10 \pm 0.03^{c}$ \\
\hline & CAT & P. pinaster & $0.85 \pm 0.19^{b}$ & $1.12 \pm 0.22^{\mathrm{a}}$ & $1.09 \pm 0.31^{\mathrm{a}}$ & $1.08 \pm 0.21^{\mathrm{a}}$ & $1.07 \pm 0.23^{\mathrm{a}}$ \\
\hline & & P. canariensis & $1.33 \pm 0.19^{\mathrm{a}}$ & $1.32 \pm 0.21^{\mathrm{a}}$ & $1.30 \pm 0.27^{\mathrm{a}}$ & $0.75 \pm 0.20^{\mathrm{b}}$ & $0.46 \pm 0.16^{b}$ \\
\hline & & $P$. radiata & $0.83 \pm 0.22^{b}$ & $0.67 \pm 0.15^{b}$ & $0.59 \pm 0.18^{b}$ & $0.38 \pm 0.13^{c}$ & $0.23 \pm 0.09^{c}$ \\
\hline
\end{tabular}

\section{$\begin{array}{lllllllllll}0 & 15 & 30 & 45 & 60 & \text { Days } & 0 & 15 & 30 & 45 & 60\end{array}$}

\section{P. radiata}

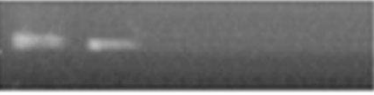

P. canariensis

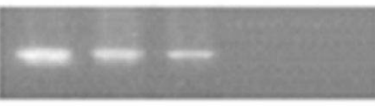

P. pinaster

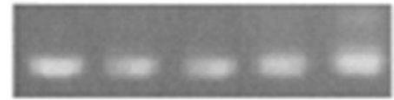

Cu-Zn-Superoxide dismutase (AF434186)
Fig. 4 - Differential gene expression in pine seedlings under stress treatment with $300 \mathrm{mM} \mathrm{CuSO}_{4}$. 
while $P$. canariensis seedlings showed gene expression in both cases at 30 days. Remarkably, consistent expression of the studied genes was demonstrated in $P$. pinasters during stress treatments (60 days). This result was in agreement with the lowest number of dead plants in this pine species.

\section{Discussion}

The present study investigated about the tolerance of Pinus spp. seedlings to abiotic stress $\left(\mathrm{CuSO}_{4}\right.$ and $\left.\mathrm{AlCl}_{3}\right)$ in ex vitro controlled conditions. The interaction between different metal stresses was not considered here, because it is known that tolerances to $\mathrm{Cu}$ and $\mathrm{Al}$ are induced by separate genetic mechanisms (Cobbett \& Goldbrough 2002, Simonovičová et al. 2004), and the probability of finding tolerant individuals to combined stress of $\mathrm{CuSO}_{4} / \mathrm{AlCl}_{3}$ would be very low. On the other hand, the highest concentration of salts (i.e., $300 \mathrm{mM}$ $\mathrm{CuSO}_{4}$ and $100 \mathrm{mM} \mathrm{AlCl}_{3}$ ) was applied for both the statistical and molecular analysis.

Our results showed that a higher number of tolerant seedlings originated from seeds collected from mother trees growing in a more severe environment. Indeed, the number of metal-tolerant seedlings obtained from the Llico provenance was largely higher $(87.4 \%)$ than those from Huilquilemu (12.6\%). Both these sites belong to the same region (Maule, Chile), but are separated by the coastal mountain range which determines highly contrasting environmental conditions between the two sites in terms of salt exposure, rain regime, soil type, etc. Moreover, Llico is a secular agroforestry system located along the coast, where pines were planted as protection barriers, while Huilquilemu is an experimental field where germplasm of different plant species is under maintenance and characterization.

The identification of the environmental factors underlying the higher metal tolerance of pine seedlings from the Llico provenance is out of the scope of this study. However, our results support the hypothesis that plant phenotype depends on genotype-environment interactions, which are specific for the area where they grow, but at the same time it could also be determined by the environment experienced by the parent trees (Boyko \& Kovalchuk 2011). Indeed, the canonical variate analysis (CVA) carried out in this study seems to support the existence of a maternal effect on seedling tolerance to $\mathrm{Cu}$ and $\mathrm{Al}$, independently from the species considered. CVA has also been used to study changes in phenolic concentrations in peach over time (Andreotti et al. 2008), as well the susceptibility to disease in monocot species and their effect on pathogen inoculum (Bithell et al. 2011).

Abiotic stress in the maternal environment has been reported to induce a "transgenerational plasticity" which could affect progeny performances (Herman \& Sultan
2011). Trans-generational plastic responses to the maternal environment are transmitted to offspring phenotypes without any change in DNA (Donohue 2002). As a source of phenotypic variation, maternal environmental effects can influence the evolutionary process and the population dynamics of many plant species (Galloway 2005, Herman \& Sultan 2011). Furthermore, increasing evidence suggests that transgenerational plasticity could be adaptive, enhancing offspring fitness under environments similar to that of the maternal environment (Galloway \& Etterson 2007). It has also been proposed to exploit such maternal environmental effects to improve the performance of tree plantations by exposing mother trees to appropriate environmental conditions (Velasco-Conde et al. 2012). The maternal environment is known to influence many traits, such as seed traits (Violle \& Jiang 2009), germination (Donohue 2002), and seedling performance (Elwell et al. 2011) in different species, including long-lived plants such as conifers (Velasco-Conde et al. 2012).

The influence of different genetic backgrounds on the tolerance to heavy metals in plants has been widely discussed (Au 2012, Prus-Glowacki et al. 2012). Crepidorhopalon perennis and C. tenuis (Linderniaceae), two metallophyte herb species from South Central Africa, have been used as models to investigate the relationship between the degree of tolerance of plants populations, bioavailable $\mathrm{Cu}$ content in the soil and the ecological isolation of endemic species (Faucon et al. 2012). Regarding forest species, resistant trees of both Pinus sylvestris L. and Pinus nigra Arn. have been reported to exhibit a lower degree of genetic variation than metal-sensitive trees with respect to some isozyme loci (SHDH A, PGI, PGM, MDH C and DIA). This allele depletion suggests that genetic changes induced by heavy metals may dramatically affect the adaptation process in forest tree populations (Chudzinska et al. 2014).

In this study, different activities of the enzymes POX, SOD and CAT were found among the three pine species from the Llico provenance, with $P$. pinaster showing the highest values. Moreover, the expression of genes coding for Cu-Zn-superoxide dismutase and Ribulose bisphosphate carboxylase (RuBisCo) was the highest in $P$. pinaster after 60-days metal treatments.

The protective functions of antioxidants from heavy metal stress have been reviewed by Schützendübel \& Polle (2002). Based on their chemical and physical properties, different molecular mechanisms of heavy metal toxicity can be distinguished: (1) production of ROS by autoxidation and the Fenton reaction, which is typical for transition metals such as iron or copper; (2) blocking of essential functional groups in biomolecules, which has been reported for non-redox reactive heavy metals such as cadmium and mercury; (3) displacement of essential metal ions from biomolecules, a reaction occurring with different kinds of heavy metals. At the plant cell level, SODs represent the first line of defense against ROS. Ozone is produced at any location where an electron transport chain is present, and $\mathrm{O}_{2}$ activation may occur in different compartments of the cell, including mitochondria, chloroplasts, microsomes, glyoxysomes, peroxisomes, apoplasts, and the cytosol (Elstner 1991, Alscher et al. 2002).

Photosynthetic activity and oxidative stress are considered sensitive biological indicators of heavy metal stress (MacFarlane \& Burchett 2001, Schützendübel \& Polle 2002). The RT-PCR analysis carried out in this study revealed a conspicuous expression of genes coding for $\mathrm{Cu}-\mathrm{Zn}$-superoxide dismutase and RuBisCo in P. pinaster (Fig. 4). These results are fairly consistent with the high levels of metal tolerance observed in $P$. pinaster, while $P$. canariensis and $P$. radiata showed intermediate and low tolerance, respectively, according to their low expression of the aforementioned genes.

The results of this study are in agreement with those reported by Acquaviva et al. (2012), who demonstrated a significant differential expression of Heat shock protein 70, Hemeoxygenase and Superoxide dismutase in $P$. pinaster trees from two sites with contrasting pollution levels. These authors proposed that the increased expression of the above enzymes may exert protective effects against oxidative stress and represent an adaptative defense mechanism. Moreover, these genes could represent useful tools for monitoring the environmental contamination and better understand the mechanisms underlying plant defense to stress. Furthermore, the response of Camellia sinensis (L.) O. Kuntze to $\mathrm{Cu}$ and $\mathrm{Al}$ stresses was investigated by Yadav \& Mohanpuria (2009). Exposure to $100 \mu \mathrm{M} \mathrm{CuSO}_{4}$ or $100 \mu \mathrm{M} \mathrm{AlCl}_{3}$ led to accumulation of higher levels of ROS in the Assamica compared to the Chinary genotype. Proline content was higher in Chinary compared to Assamica, while chlorophyll and protein contents decreased upon $\mathrm{Cu}$ and $\mathrm{Al}$ exposure in both varieties. Phytochelatin synthase (PCS), an enzyme involved in phytochelatin synthesis by using glutathione as a substrate, was upregulated to the highest levels in Chinary. These results suggest that the Chinary could be more $\mathrm{Cu}$ - and Al-tolerant than the Assamica genotype.

In conclusion, $P$. pinaster has shown the best tolerance to both $\mathrm{Cu}$ and $\mathrm{Al}$ under controlled conditions in terms of plant survival and detoxifying enzyme activity. Tolerant individuals of all the species studied have been selected and planted in a local mining ecosystem, which is particularly vulnerable to heavy metal pollution. Epigenetic analysis will be conducted in selected individuals in future studies. 


\section{Acknowledgements}

The authors thank Science Editing Chile for language revision and copy-editing of the manuscript. This project was financed by the Catholic University of Maule (UCM) and the Regional Government of Maule, Chile, Project BIP 30.386.978-0.

\section{References}

Acquaviva R, Vanella L, Sorrenti V, Santangelo R, lauk L, Russo A, Savoca F, Barbagallo I, Di Giacomo C (2012). Biochemical modifications in Pinus pinaster Ait. as a result of environmental pollution. Environmental Science Pollution Research 19: 3850-3858. - doi: 10.1007/s11356-0121030-x

Alscher RG, Erturk N, Heath LS (2002). Role of superoxide dismutases (SODs) in controlling oxidative stress in plants. Journal of Experimental Botany 53: 1331-1341. - doi: 10.1093/jex bot/53.372.1331

Andreotti C, Ravaglia D, Ragaini A, Costa G (2008). Phenolic compounds in peach (Prunus persica) cultivars at harvest and during fruit maturation. Annals of Applied Biology 153: 1123. - doi: 10.1111/j.1744-7348.2008.00234.x

Apel K, Hirt H (2004). Reactive oxygen species: metabolism, oxidative stress, and signal transduction. Annual Review of Plant Biology 55: 373-399. - doi: 10.1146/annurev.arplant.55.0319 03.141701

Au DWT (2012). New directions in ecotoxicology and meeting the challenges ahead. Environmental Science and Pollution Research 19 (7): 2463-2464. - doi: 10.1007/s11356-012-1001-2

Baize D (2009). Cadmium in soils and cereal grains after sewage-sludge application on French soils. A review. Agronomy for Sustainable Development 29: 175-184. - doi: 10.1051/ agro:2008031

Bania I, Mahanta R (2012). Evaluations of peroxidase from various plant sources. International Journal of Scientific and Research Publications 2: $1-5$.

Beers RF, Sizer IW (1952). A spectrophotometric method for measuring the breakdown of hydrogen peroxide by catalase. Journal of Biological Chemistry 195: 133-140.

Bithell SL, Butler RC, Harrow S, McKay A, Cromey MG (2011). Susceptibility to take-all of cereal and grass species, and their effects on pathogen inoculum. Annals of Applied Biology 159: 252-266. - doi: 10.1111/j.1744-7348.2011.004 93. $x$

Boscolo PRS, Menossib M, Jorgea RA (2003). Aluminum induced oxidative stress in maize. Phytochemisty 62: 181-189. - doi: 10.1016/So0319422(02)00491-0

Boyko A, Kovalchuk I (2011). Genome instability and epigenetic modification-heritable responses to environmental stress? Current Opinion in Plant Biology 14: 260-266. - doi: 10.1016/ j.pbi.2011.03.003

Bray E, Bailey-Serres J, Weretilnyk E (2000). Responses to abiotic stresses. In: "Biochemistry and molecular biology of plants" (Buchanan B, Gruissem W, Jones R eds). American Society of Plant Physiologists, Rockville, MD, USA, pp. 1158-1203.

Cankaya S, Balkaya A, Karaagac O (2010). Canonical correlation analysis for the determination of relationships between plant characters and yield components in red pepper [Capsicum annuum L. var. conoides (Mill.) Irish]. Spanish Journal of Agricultural Research 8: 67-73. - doi: 10.5424/sjar/2010081-1144

Chudzinska E, Diatta JB, Wojnicka-Póltorak A (2014). Adaptation strategies and referencing trial of Scots and blackpine populations subjected to heavy metal pollution. Environmental Science Pollution Research 21: 2165-2177. - doi: 10.1007/s11356-013-2081-3

Cobbett C, Goldbrough PB (2002). Phytochelatins and metallathioneins: roles in heavy metal detoxification and homeostasis. Annual Review of Plant Biology 53: 159-182. - doi: 10.1146/ annurev.arplant.53.100301.135154

Coleman TW, Clarke SR, Meeker J, Rieske LK (2008). Forest composition following overstory mortality from southern pine beetle and associated treatments. Canadian Journal of Forest Research 38: 1406-1418. - doi: 10.1139/X07-248

Donohue K (2002). Germination timing influences natural selection on life-history characters in Arabidopsis thaliana. Ecology 83: 10061016. - doi: 10.1890/0012-9658(2002)083[1006: GTINSO]2.0.CO;2

Elstner EF (1991). Mechanisms of oxygen activation in different compartments of plant cells. In: "Active oxygen/oxidative stress and plant metabolism" (Pell EJ, Steffen KL, eds). American Society of Plant Physiologists, Rockville, MD, USA, pp. 13-25.

Elwell AL, Gronwall DS, Miller ND, Spalding EP, Durhambtl DS (2011). Separating parental environment from seed size effects on next generation growth and development in Arabidopsis. Plant, Cell and Environment 34: 291-301. - doi: 10.1111/j.1365-3040.2010.02243.x

Faucon M, Chipeng F, Verbruggen N, Mahy G, Colinet G, Shutcha M, Pourret O, Meerts $P$ (2012). Copper tolerance and accumulation in two cuprophytes of South Central Africa: Crepidorhopalon perennis and C. tenuis (Linderniaceae). Environmental and Experimental Botany 84: 11-16. - doi: 10.1016/j.envexpbot.2012. 04.012

Foyer CH, Noctor G (2005). Redox homeostasis and antioxidant signaling: a metabolic interface between stress perception and physiological responses. The Plant Cell 17: 1866-1875. - doi: 10.1105/tpc.105.033589

Galloway LF (2005). Maternal effects provide phenotypic adaptation to local environmental conditions. New Phytologist 166: 93-100. - doi: 10.1111/j.1469-8137.2004.01314.x

Galloway LF, Etterson JR (2007). Transgenerational plasticity is adaptive in the wild. Science 318: 1134-1136. - doi: 10.1126/science.1148766

Giannakoulas A, Moustakas M, Syros T, Yupsanis $T$ (2010). Aluminum stress induces up-regulation of an efficient antioxidant system in the Altolerant maize line but not in an Al sensitive line. Environmental and Experimental Botany 67: 487-494. - doi: 10.1016/j.envexpbot.2009.07. 010

Hall JL (2002). Cellular mechanisms for heavy metal detoxification and tolerance. Journal of Experimental Botany 53: 1-11. - doi: 10.1093/jex bot/53.366.1

Herman JJ, Sultan SE (2011). Adaptive trans-generational plasticity in plants: case studies, me- chanisms, and implications for natural populations. Frontiers in Plant Sciences 2: 1-10.

Kumar M, Yadav V, Tuteja N, Tohri AK (2009). Antioxidant enzyme activities in maize plants colonized with Piriformospora indica. Microbiology 155: 780-790. - doi: 10.1099/mic.0.019869-0 Matsumoto H (2000). Cell biology of aluminum toxicity and tolerance in higher plants. International Review of Cytology 200: 1-46. - doi: 10.1016/S0074-7696(00)00001-2

MacFarlane GR, Burchett MD (2001). Photosynthetic pigments and peroxidase activity indicators of heavy metal stress in the Grey Mangrove, Avicennia marina (Forsk.) Vierh. Marine Pollution Bulletin 42: 233-240. - doi: 10.1016/ S0025-326X(00)00147-8

Mazen A, Faheed FA, Ahmed AF (2010). Study of potential impacts of using sewage sludge in the amendment of desert reclaimed soil on wheat and jews mallow plants. Brazilian Archive of Biology and Technology 53: 917-930. - doi: 10.1590/S1516-89132010000400022

Mittler R, Vanderauwera S, Gollery M, Van Breusegem $F$ (2004). The reactive oxygen gene network in plants. Trends in Plant Sciences 9: 490498. - doi: 10.1016/j.tplants.2004.08.009

Parra S, Bravo MA, Quiroz W, Moreno T, Karanasiou A, Font O, Vidal V, Cereceda F (2014). Distribution of trace elements in particle size fractions from contaminated soils by a copper smelting from different zones of the Puchuncavi Valley (Chile). Chemosphere 111: 513-521. doi: 10.1016/j.chemosphere.2014.03.127

Prus-Glowacki W, Urbaniak L, Bujas E, Curthus $A L$ (2012). Genetic variation of isolated and peripheral populations of Pinus sylvestris (L.) from glacial refugia. Flora - Morphology, Distribution, Functional Ecology of Plants 207: 150158. - doi: 10.1016/j.flora.2011.11.006

Roth EF, Gilbert HS (1984). Pyrogallol assay for SOD: absence of a glutathione artifact. Analytical Biochemistry 137: 50-53. - doi: 10.1016/00032697(84)90344-0

Schützendübel A, Polle A (2002). Plant responses to abiotic stresses: heavy metal induced oxidative stress and protection by mycorrhization. Journal of Experimental Botany 53: 1351-1365. - doi: 10.1093/jexbot/53.372.1351 Sharma P, Dubey RS (2007). Involvement of oxidative stress and role of antioxidative defense system in growing rice seedlings exposed to toxic concentrations of aluminum. Plant Cell Reports 11: 2027-2038. - doi: 10.1007/s00299-0070416-6

Simonovičová M, Huttová J, Mistrík I, Siroká B, Tamás L (2004). Root growth inhibition by aluminum in probably caused by cell death due to peroxidase-mediated hydrogen peroxide production. Protoplasma 224: 91-98.

Ter Braak CJF (1986). Canonical correspondence analysis: a new eigenvector technique for multivariate direct gradient analysis. Ecology 67: 1167-1179. - doi: 10.2307/1938672

Velasco-Conde T, Yakovlev I, Majada JP, Aranda I, Johnsen O (2012). Dehydrins in maritime pine (Pinus pinaster) and their expression related to drought stress response. Tree Genetics and Genomes 8: 957-973. - doi: 10.1007/s11295-012-047 6-9

Violle C, Jiang L (2009). Towards a trait-based quantification of species niche. Journal of Plant 
Ecology 2: 87-93. - doi: 10.1093/jpe/rtpoo7 Wannaz ED, Carreras HA, Pérez CA, Pignata ML (2006). Assessment of heavy metal accumulation in two species of Tillandsia in relation to atmospheric emission sources in Argentina. Science of the Total Environment 361: 267-278. doi: 10.1016/j.scitotenv.2005.11.005

Yadav SK, Mohanpuria P (2009). Responses of
Camellia sinensis cultivars to $\mathrm{Cu}$ and $\mathrm{Al}$ stress. Biologia Plantarum 53: 737-740. - doi: 10.1007/ 510535-009-0134-8

Yang L, Zambrano Y, Hu CJ, Carmona ER, Bernal A, Pérez A, Zayas CM, Li YR, Guerra A, Santana I, Arencibia AD (2010). Sugarcane metabolites produced in $\mathrm{CO}_{2}$-rich temporary immersion bioreactors (TIBS) induce tomato (Solanum lycopersicum) resistance against bacterial wilt (Ralstonia solanacearum). In Vitro Cellular and Developmental Biology - Plant 46 (6): 558-568. doi: 10.1007/s11627-010-9312-9

Yamamoto Y, Kobayashi Y, Devi SR, Rikiishi S, Matsumoto $\mathrm{H}$ (2003). Oxidative stress triggered by aluminum in plant roots. Plant and Soil 255 (1): 239-243. - doi: 10.1023/A:1026127803156 